\title{
The influence of image consciousness, materialism and compulsive spending on credit card usage intentions among youth
}

\author{
Joyce K.H. Nga, Lisa H.L. Yong and Rathakrishnan Sellappan
}

Joyce K.H. Nga is based at the School of Business, Sunway University, Bandar Sunway, Malaysia. Lisa H.L. Yong and Rathakrishnan Sellappan are both based at Taylor's University, Subang Jaya, Malaysia.
Received: September 2010 Revised: February 2011 Accepted: March 2011

\begin{abstract}
Purpose - This study aims to bridge the gap in the literature on consumer behaviours such as image consciousness, materialism and consumer spending on credit card usage intentions among Malaysian college students.
\end{abstract}

Design/methodology/approach - A purposive sampling design was employed using a sample of 191 business and management students at a private higher education institution in Subang Jaya, Malaysia. An anonymous survey questionnaire was administered to the students. Structural equation modeling was then used to determine the validity of the path diagram and model fit.

Findings - The findings of the study revealed that materialism is a partial mediator in the relationship between image consciousness and compulsive spending. The study also found that compulsive spending is not a mediator in the relationship between materialism and credit card usage intentions. However, compulsive spending does exert a sizable influence.

Research limitations/implications - Future research is required to investigate whether family background has an impact on youth abilities to be more responsible and rational when undertaking more lavish lifestyles and credit.

Practical implications - The implication of this study is that there needs to be more concerted efforts made in instilling credit card awareness and financial discipline among youth to avoid them falling into the debt trap at an early age.

Originality/value - This study highlighted the existence of the credit card debt problem which can inhibit Malaysia's vision to achieve a developed nation status in 2020.

Keywords Consumer behaviour, Image consciousness, Materialism, Compulsive spending, Financial management, Malaysia, Students

Paper type Research paper

\section{Study background}

Generation $Y$ is often characterized by attributes including technological suaveness, inflated self-esteem, fashion consciousness and the need for greater social approval (Twenge and Campbell, 2008; Heaney, 2007). This generation has been found to succumb to advertising through mass media and the internet and thrive on instant gratification (Xu, 2007). Their greater image consciousness may lead them to perceive that a materialistic lifestyle can provide the identity of success. As a result of social pressures and materialism, it is widely documented that compulsive spending and excessive debt is rampant among today's youth (Penman and McNeill, 2008; Pirog and Roberts, 2007; Xu, 2007).

Credit card bankruptcy among Malaysian youth has grown from 2.10 percent in 2006 to 7.63 percent in 2007 (Goi and Nee, 2008). High credit card delinquencies and lackadaisical attitude towards debt among youth were also found in prior studies in USA, Canada, Ireland and UK (Lachance et al., 2006; O'Loughlin and Szmigin, 2006; Austin and Phillips, 2001; Warwick and Mansfield, 2000). The need for instant gratification, ease of access to credit cards, lack of awareness and accountability of the consequences of excess debt has contributed to the severity of the problem. 
Although there are studies investigating the mediating effects of credit card use on fashion consciousness and compulsive spending in Western countries, there is a dearth of studies linking materialism to credit card use. This study bridges this knowledge gap by investigating whether materialism and compulsive spending mediates the relationship between image consciousness and credit card usage intentions. The variables of this study have been identified based on an extant review of literature. The findings of this study have implications on enhancing financial planning education and in promoting responsible spending discipline among Malaysian youth.

The research questions of this study are as follows:

$R Q 1$. Does materialism mediate the relationship between image consciousness and compulsive spending?.

$R Q 2$. Does compulsive spending mediate the relationship between materialism and credit card usage intentions?

Figure 1 represents the conceptual framework for this study.

\section{Review of literature \\ Image consciousness}

Image consciousness is the perception that social approval can fill the lack of self-esteem within individuals (Silvera et al., 2008; Xu, 2007). The greater exposure to media sources has reinforced the belief that material possessions can promote a favourable social status (Bakewell and Mitchell, 2003). The social pressure to portray the desired social status may drive image conscious individuals into patronizing the latest trends in fashion and lifestyle. The aggressiveness of media and brand advertising has also driven young individuals to be self-indulgent in consumption.

\section{Materialism}

Materialism is a trait that emphasizes possessions as central to an individual's identity attribution to success (Schiffman and Kanuk, 2007 pp. 128-129). In a competitive environment, the pursuit of social status via material possessions has contributed to credit card misuse and splurge spending (Pirog and Roberts, 2007; Fitzmaurice, 2008). Status consumption was found to have a significant positive relationship with materialism and social information comparison in Malaysian students (Heaney et al., 2005). Materialistic individuals have been found to be less satisfied and are more likely to be compulsive spenders (Stone et al., 2008).

\section{Compulsive spending}

Compulsive spending implies repeated, obsessive, unbudgeted and often chronic excessive spending undertaken to compensate for lack of self-esteem, boredom, tension and anxiety (Shoham and Brenčič, 2003). The reasons for compulsive spending range from

Figure 1 Conceptual framework of the study

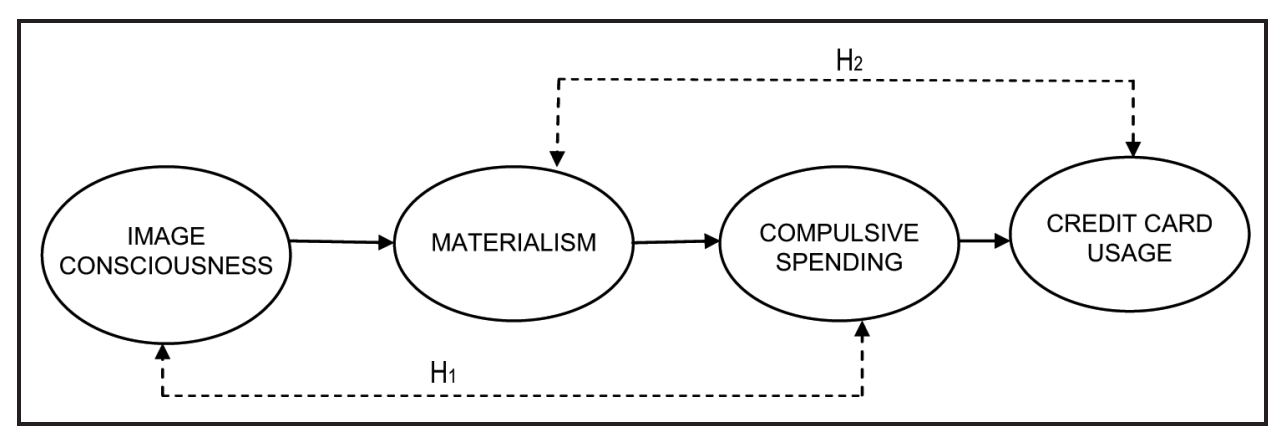

PAGE 244 | YOUNG CONSUMERS | VOL. 12 NO. 32011 
the desire to be socially accepted, entertainment, self-gifting and easy access to credit (Penman and McNeill, 2008). Past studies have found significant positive relationships between fashion orientations in both impulsive and compulsive spenders (Park et al., 2006; Park and Burns, 2005). Impulsive spending occurs spontaneously in response to in-store stimulus that captivates and provides self-justification of a need. On the other hand, compulsive spending is an addictive form of compensatory consumption (Shoham and Brenčič, 2003; Bayley and Nancarrow, 1998; Woodruffe, 1997). Compulsive spending can be attributed to a combination of psychological, genetic, cultural and social factors (O'Guinn and Faber, 1989 cited in Kwak et al., 2004). These factors cause individual's to manifest obsessive thoughts and risk taking propensities which have been found to positively influence compulsive spending, gambling and drug abuse (Kwak et al., 2004).

Compulsive spending may provide temporary gratification, boost self-esteem and provide mood relief (Saravena and Sääksjärvi, 2008). Females and young adults are often likely to be compulsive spenders (Saravena and Sääksjärvi, 2008; Penman and McNeill, 2008; Shoham and Brenčič, 2003).

\section{Credit card usage intentions}

Credit cards are often used to complement certain lifestyle preferences (Brenthal et al., 2005). It is a double-edged sword. On one hand it creates opportunities for individuals to make certain purchases that they otherwise cannot afford. On the other hand it may be a stumbling block if individuals are unable to exercise control on their spending. Credit cards may provide a source of contingent funds in times of need. Responsible credit card usage entails self-control over material constraints and prudent financial planning. Hayhoe et al. (2000) found that female youth are more likely to employ financial planning practices such as budgeting. However, there were no gender differences in credit card payment behaviour. They also found that females were more likely to spend on clothing items while males on entertainment, electronic goods and food.

The youth market has been recognized as a lucrative target segment for credit card marketing (Kara et al., 1994). Youth are more easily lured by the modern lifestyle, shopping and special packages (including free gifts) offered by credit card firms (Bianco and Bosco, 2002). They also have longer-term earnings and spending potential. Credit card firms often leverage on these lifestyle drivers to build long-term brand loyalty. Their need for short-term self-gratification without a good grounding on the consequences of excess debt may lead to high interest burdens, default and ultimately bankruptcy. Students often do not spend enough time researching credit card terms and are not aware of the applicable interest rates (Warwick and Mansfield, 2000). High debt levels of freshman have been found to contribute to lower grades and higher dropouts (Cummins et al., 2005).

Convenience credit card users are more likely to settle the entire credit balance every month while instalment users or revolvers are likely to pay the minimum credit balance (Rutherford and DeVaney, 2009; D'Astous and Miquelon, 1991). There is lack of research in this area in Malaysia, however, a study in the USA found that the most important considerations by youth on credit cards are the applicable interest rates and duration of deferred payment (Kara et al., 1994).

With effect from 1 April 2009, commercial banks in Malaysia have lowered credit card interest in tiers ranging from 13.5 percent to 17.5 percent depending on the payment patterns of customers in the past 12 consecutive months (The Association of Banks Malaysia, 2009). This change was implemented to help credit card holders cope with the higher debt burdens arising from the financial crisis of 2008/2009. However, in the Malaysian Budget 2010, a RM50 service tax was imposed to prevent over-reliance on credit card spending. The service charge will cause individuals to reconsider the opportunity costs of holding multiple credit cards.

In order to answer research question 1, the following hypothesis has been posited:

H1. Materialism mediates the relationship between image consciousness and compulsive spending.

VOL. 12 NO. 32011 YOUNG CONSUMERS | PAGE 245 
Higher urge to purchase has been found in individuals with low self esteem (Shoham and Brenčič, 2003; D'Astous, 1990). In an Australian study, the perception of power and prestige was found to be higher among compulsive spenders (Phau and Woo, 2008). In line with this, a Singaporean study found that low-income earners held credit cards as a symbol of social status achievement (Gan et al., 2008). Higher degree of materialism has been found among consumers that splurged on expensive tangible items which contributed to post-purchase guilt emotions (Fitzmaurice, 2008). Splurge spending is often undertaken to keep up with peer pressure (Rutherford and DeVaney, 2009). The centrality of possessions was found to be a partial mediator between public self-image and compulsive purchasing among youth in a USA study (Xu, 2007). Synthesizing the studies above, it is hypothesized that the need to maintain a preferred social image among peers leads to materialism that results in compulsive spending.

To address research question 2, the following hypothesis has been posited

H1. Compulsive spending mediates the relationship between materialism and credit card usage intentions.

Easy access and rampant solicitation of youth by credit card issuers have made credit card usage as a mode of meeting material constraints in the modern lifestyle and self-expression (O'Loughlin and Szmigin, 2006; Brenthal et al., 2005). The availability of credit cards has also created an additional source of short-term funds. College students are often unrealistically optimistic about their ability to repay debt and are not concerned about the future adverse interest rates and other consequences (Warwick and Mansfield, 2000).

As discussed previously, there are generally two broad categories of credit cardholders namely convenience and revolving users (Rutherford and DeVaney, 2009; D'Astous and Miquelon, 1991). Users who perceived that credit card is of high risk were more likely to be convenience users who avoided accumulating credit card balances. Occasional splurge purchases may cause convenience users to switch to a revolving use of credit cards (Rutherford and DeVaney, 2009). The increased impulsiveness to spend has also been found to lead to misuse of credit cards (D'Astous, 1990). In an all female Korean study, credit card use was found to mediate fashion orientation and compulsive purchases (Park and Burns, 2005). As such, this hypothesis posits that compulsive spending will mediate the relationship between materialism and credit card usage intentions. It is likely that compulsive spending would have a negative relationship with responsible credit card usage.

\section{Methodology \\ Sampling design}

The purpose of this study is to assess the theoretical rather than population generalizability of the conceptual framework in Figure 1. As such, a purposive sampling design is employed. There were a total of 191 respondents comprising business and management students at a private higher education provider in Subang Jaya, West Malaysia who voluntarily responded to a survey questionnaire. These students were selected because they have undertaken courses that have exposed them to personal financial planning and budgeting.

\section{Measurement assessment}

\section{Validity}

The scale used in the survey questionnaire is shown in the Appendix (Figure A1). The questionnaire has four sections. The headings have been disguised to reduce social desirability bias. Part A, B C and D measures image consciousness, compulsive spending, credit card usage and materialism constructs respectively. The survey questions were developed for this study based on the review of extant literature above.

The validity of the constructs of this study namely image consciousness, materialism, compulsive spending and credit card usage intentions are assessed via exploratory factor analysis (EFA) using SPSS PASW 18. The principal component extraction method and the 
Direct Oblimin rotation method are used to account for correlated factors. The Kaiser Mayer Olkin Sample Adequacy (KMO) of at least 50 percent and Bartlett's Test of Sphericity with a significant Chi-Squared $(p<0.01)$ are used to assess the suitability of the sample data for conduct of EFA. Valid factors are identified based on the Eigenvalues of at least 1. Factor loadings of above 0.45 are considered significant in line with a sample size between 150 to 200 (Hair et al., 2010, p. 117).

\section{Reliability}

The Cronbach's Alpha threshold value of 0.70 is used to determine reliability of the scale representing the construct (Nunnally, 1967, cited in Peterson, 1994; Hair et al., 2010). A summated scale is created based on the valid and reliable items of each construct which is then employed in further data analysis procedures described below.

\section{Data analysis}

The two hypotheses of this study are tested via structural equation modelling using SPSS AMOS 18. The purpose is to investigate whether materialism and compulsive spending mediate the relationship between image consciousness and credit card usage intentions respectively.

The model estimation is derived using the Maximum Likelihood method. The bootstrapping procedure with 1,500 iterations is employed to promote greater parameter estimate stability and model accuracy. Goodness of fit statistics thresholds used are Chi-Squared/Degrees of freedom (below 3), GFI and AGFI (at least 0.9) and root mean square error of approximation (RMSEA) with p-values of less than 0.05 (Bryne, 2010 pp. 73-84; Blunch, 2008 pp. 110-118). As for parsimony statistics, the Comparative Fit Index (CFI) and Akaike's Information Criterion (AIC) statistics are used to assess comparative fit between working models. The higher the $\mathrm{CFI}$ and the lower the AIC the better the comparative model fit.

Mediating effects are assessed based on a comparison of the direct effects (a) and indirect effects ( $b$ and $c$ ) as shown in Figure 2. According to Baron and Kenny (1986) a mediating effect exists if either of the following two conditions is fulfilled.

1. Full mediation - If $a$ is not significant but $b$ and $c$ are significant.

2. Partial mediation - If $\mathrm{a}$ is significant and $\mathrm{b}$ and $\mathrm{c}$ are significant.

The strongest form of mediation effect is when $a$ is zero and insignificant while $b$ and $c$ are non-zero and significant. A sizable mediating effect is deemed to exist if the indirect effect is greater than 0.08 (Hair et al., 2010).

\section{Findings}

\section{Descriptive statistics}

There were 191 usable questionnaires received from students pursuing business and management courses. A majority were females (61.8 percent). Of the respondents,

\section{Figure 2 Assessing mediating effects}

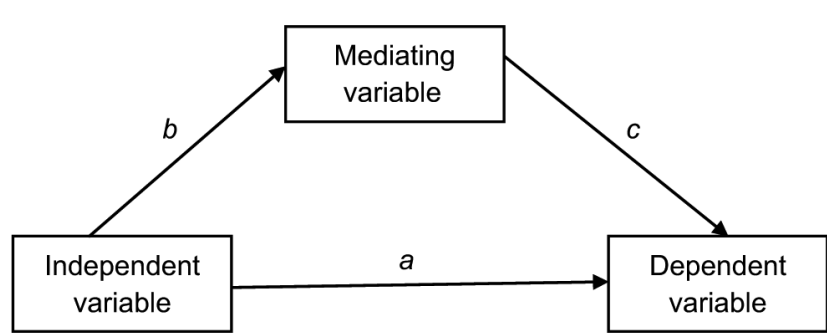

Source: Baron and Kenny (1986) 
33 percent are credit card holders with 18.8 percent who have held them for more than a year.

\section{Validity and reliability}

The Kaiser-Mayer-Olkin measure of sample adequacy was 0.79 and the Bartlett's Test of Sphericity yielded a chi-square of 1197.9 ( $\mathrm{df}=190 ; p<0.05)$. This indicates that the sample meets the assumptions and is appropriate for the conduct of EFA.

All the constructs of the study had eigenvalues greater than 1. The cumulative percentage of variance explained by the four constructs of the study was 53.44 percent. The Cronbach's alpha for image consciousness (0.83), compulsive spending (0.71), credit card usage intentions (0.71) and materialism (0.79) are all above 0.70 indicating that the respective scales which have been developed for this study have also achieved statistical reliability (Nunnally, 1967, cited in Peterson, 1994; Hair et al., 2010).

\section{Hypothesis testing}

The path diagram linking constructs of this study are shown in Figure 3. The overall model fit were assessed based on chi-squared/degrees of freedom of 0.064 (below 3), GFI and AGFI (above 0.90) and RMSEA of 0.01 (below 0.05). The error terms were linked to stabilize the model.

There are significant positive relationships between image consciousness and materialism and between materialism and compulsive spending. However, the relationship between compulsive spending and credit card usage intentions is not significant $(p>0.05)$. The standardized regression coefficients between image consciousness, materialism, compulsive spending and credit card usage intentions are $0.484,0.693$ and 0.196 respectively.

The direct effect of materialism on image consciousness is as follows:

\section{IMAGE CONSCIOUSNESS $=6.269+0.236$ COMPULSIVE SPENDING}

Compulsive spending has a significant positive relationship on image consciousness $(F=24.05 ; p<0.05$; Adjusted $R$-squared $=10.8$ per cent; Beta $=0.336)$. Integrating the findings of the path diagram in Figure 3 and the above relationship, materialism is a partial mediator of the relationship between image consciousness and compulsive spending. The indirect effect is $0.3354(=0.484 \times 0.693)$ is greater than the threshold of 0.08 (Hair et al., 2010) indicating that materialism exerts a sizeable mediating effect. As such, $H 1$ is partially supported.

As for the direct effect of materialism on credit card usage intentions, the regression equation is as follows:

\section{CREDIT CARD USAGE $=9.139+0.33 \quad$ MATERIALISM}

This indicates that the relationship between materialism and credit card usage is not significant $(F=0.627 ; p>0.05)$. While the relationship between compulsive spending and

\section{Figure 3 Final structural path diagram}

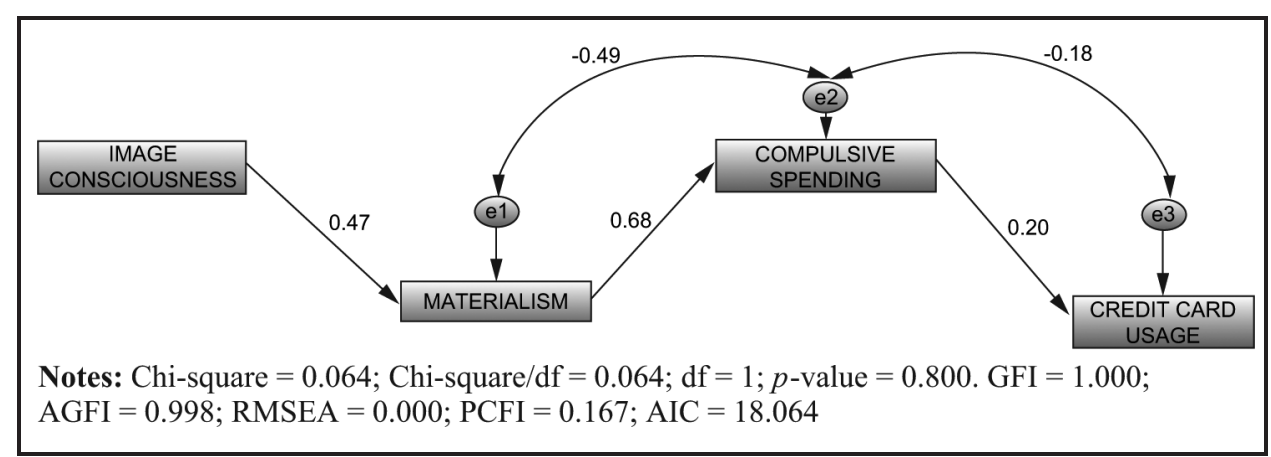

PAGE 248 | YOUNG CONSUMERS | VOL. 12 NO. 32011 
materialism is significant, the relationship between compulsive spending and credit card usage intentions is not significant. The indirect effect of compulsive spending on materialism and credit card usage based on the path diagram in Figure 3 is $0.1358(=0.693 \times 0.196)$ is greater than 0.08 (Hair et al., 2010). This indicates that compulsive spending may exert some weak mediating influence between materialism and credit card usage intentions even though it may not fit the characteristics of a full or partial mediator. As such $\mathrm{H} 2$ is not fully supported.

\section{Discussion and implications}

\section{Financial planning education}

As the findings of the study indicates that compulsive spending behaviours have some mediating influence on the relationship between materialism and credit card usage intentions, this would mean that youth need to be made aware of the consequences of high credit card balances. While the theoretical knowledge is important there needs to be more practical methods of reinforcing awareness on the benefits and risks of credit card usage towards one's long-term financial well-being. Youth have often displayed low financial knowledge, apathy and lack of motivation in seeking financial literacy (Mandell and Klein, 2007). Financial education can supplement rational decision-making but this is dependent upon the readiness of individuals to embrace its importance (Robb and Sharpe, 2009). Educational courses assist more in behavioural rather than attitudinal modifications (Lachance and Legault, 2007). As such, educators need to assume the role as mentors and constantly remind students that their current financial decisions will have an impact on their future economic well-being and financial freedom.

In order to foster greater engagement, financial planning courses may need to include projects that require students to prepare real financial plans for a household incorporating credit card spending. Simulation games based on case studies can also be used to replicate real world experiences. Students should learn not to embrace materialistic temptations. Financial discipline needs to be reinforced wherever possible in business, economics and other finance related courses (Cummins et al., 2005).

In Malaysia, the Agensi Kaunseling dan Pengurusan Kredit ("AKPK") has been set up under the umbrella of Central Bank to provide free credit counselling and debt management advice to individuals. Private institutions of higher learning could work together with AKPK to develop more engaging and relevant financial planning education curriculum that incorporates real life examples of credit card default cases. Business students can also be provided training to be responsible counsellors under the mentorship of more senior personnel as part of an internship programme. This may help provide practical relevance to the theoretical knowledge learnt in the classroom.

While restricting credit cards may not be the answer in coping with the modern lifestyle, responsible credit card usage is (Robb and Sharpe, 2009). Responsible credit card usage would include seeking knowledge on features of different credit cards, interest rates, the charges on making partial payments, billing cycles and cost of reward programmes (Hoffman et al., 2008) as well as mastery over the individual's needs versus wants. Responsible spending will reduce the default rates, reduce litigation and recovery costs, produce good quality credit card holders who are loyal and sustain the profitability of credit card issuers. As such, private institutions of higher learning can also work together with credit card companies (mostly banks in Malaysia) to develop and reinforce responsible credit card usage among youth.

The variety of institutional collaborations above are suggested with the intention of making financial planning courses more relevant as well as provide independent and unbiased views on credit card usage (Hoffman et al., 2008). It may be necessary for financial planning to be introduced as early as in primary education level and be a compulsory course in a business degree at the university level. Professional bodies such as the Financial Planning Association of Malaysia (FPAM) may be consulted on curriculum design and to provide joint recognition to provide greater motivation to students to undertake credible financial planning courses. 
The results of this study also shows that materialism mediates image consciousness and compulsive spending. Compulsive spending tendencies have also been found to be influenced by an individual's upbringing. Consumer and financial competence is often learnt through informal support networks such as peers, parents and via media influences (Lachance and Legault, 2007). Guidance from social networks comprising family members and friends has been found to be an important determinant of purchasing decisions made by young adults (Grønhøj, 2007). Similarly, social networks and personal trial and error have been cited as the primary sources of credit card information (Lachance et al., 2006). As such, there is increasingly convincing evidence that financial education begins in the family setting. Parents need to assume responsibility to instil financial discipline among their children and be role models in financial planning. Parents need to inculcate the virtues of hard work, living within one's means and being realistic about their credit capacity among these vulnerable youth.

Parents need to instil good values and a healthy self-image in young adults. Young adults need to be able to accept that happiness is not always derived from material possessions. They need to be responsible, rational and realistic about their abilities to cope with their desired lifestyles on credit.

\section{Regulations on credit card disclosures and solicitations}

The existence of some mediating influence between compulsive spending and credit card usage intentions found in this study may be fuelled by the high credit card solicitations among youth. Credit card salespersons are commission based and thrive on just making sales. Young consumers are often tempted by free gifts and promotions offered by credit card providers. In fact, there have been cases where these agents have advised consumers to subscribe to credit cards to receive the free gift and immediately cancel them later on. These marketing efforts may seem unethical especially in luring vulnerable young adults. To mitigate this unhealthy trend, credit card companies need to ensure that their salespersons are trained to brief potential cardholders as part of their standard operating procedures on the interest and fees applicable and only recommend appropriate credit cards that suit the needs of their consumers.

In Malaysia, any individual above the age of 18 can possess a credit card. According to The Star Online, 8 September 2010 credit limits generally range between 2.5 to 3 times their salaries There is also no limit to the number of credit cards an individual can hold. Perhaps, there should be stricter regulations such as increasing the minimum age, lowering the credit limit and number of credit cards an individual can possess. There should also be a national central database where individual credit card payment history are kept, Debt laden households will burden the citizens of the country and may thwart the achievement of a developed nation status in Vision 2020.

\section{Further research}

Further research should focus on whether financial education, business majors and age influence the relationship between compulsive spending and credit card usage.

\section{Conclusion}

The study reinforces previous studies on the mediation effect of materialism on image consciousness and compulsive spending. Although compulsive spending was not a full mediator in the relationship between materialism and credit card usage, the sizeable indirect effect shows that it does exert some influence.

The implication of this study is that there is a need for more relevant financial planning education and discipline among youth especially in business and management courses. Financial discipline needs to start at an early age at home and be reinforced in the Malaysian education system. The credit card debt problem among youth needs to be addressed urgently in order not to hamper the achievement of the developed nation status by 2020.

PAGE 250 Y YOUNG CONSUMERS | VOL. 12 NO. 32011 


\section{References}

(The) Association of Banks Malaysia (2009), "Banks lower credit card interest rates to help customers cope with weakening economic indicators" The Association of Banks Malaysia, available at: www.abm. org.my/Banks_Lower_Credit_Card_Interest_Rates_To_Help_Customers_Cope_With_Weakening_ Economic_Indicators.aspx (accessed 18 August 2010).

Austin, M.J. and Phillips, M.R. (2001), "Educating students: an ethics responsibility of credit card companies", Journal of Services Marketing, Vol. 15 No. 7, pp. 516-28.

Bakewell, C. and Mitchell, V. (2003), "Generation Y female consumer decision making styles", International Journal of Retail \& Distribution Management, Vol. 31 No. 2, pp. 95-106.

Baron, R.M. and Kenny, D.A. (1986), "The moderator-mediator distinction in social psychological research: conceptual, strategic and statistical considerations", Journal of Personality and Social Psychology, Vol. 51 No. 6, pp. 1173-82.

Bayley, G. and Nancarrow, C. (1998), "Impulse purchasing: a qualitative exploration of the phenomenon", Qualitative Market Research: An International Journal, Vol. 1 No. 2, pp. 99-114.

Bianco, C.A. and Bosco, S.M. (2002), "Ethical issues in credit card solicitation of college students the responsibilities of credit card issuers, higher education and students", Teaching Business Ethics, Vol. 6 No. 1, pp. 45-62.

Blunch, N.J. (2008), Introduction to Structural Equation Modelling Using SPSS and AMOS, Sage Publications, Newbury Park, CA.

Brenthal, M.J., Crockett, D. and Rose, R.L. (2005), "Credit card as lifestyle facilitators", Journal of Consumer Research, Vol. 32, pp. 130-45.

Bryne, B.M. (2010), Structural Equation Modelling with AMOS: Basic Concepts, Applications and Programming, 2nd ed., Routledge Taylor Francis Group, New York, NY.

Cummins, M.M., Haskell, J.H. and Jenkins, S.J. (2005), "Financial attitudes and spending habits of university freshmen", Proceedings of The Academy for Economics and Economic Education, Vol. 8 No. 1, pp. 3-6.

D'Astous, A. (1990), "An inquiry into the compulsive side of 'normal' consumers", Journal of Consumer Policy, Vol. 13 No. 1, pp. 15-31.

D'Astous, A. and Miquelon, D. (1991), "Helping consumers choose a credit card", Journal of Consumer Affairs, Vol. 25 No. 2, pp. 278-94.

Fitzmaurice, J. (2008), "Splurge purchases and materialism", Journal of Consumer Marketing, Vol. 25 No. 6, pp. 332-8.

Gan, L.L., Maysami, R.C. and Koh, H.C. (2008), "Singapore credit cardholders: ownership, usage patterns and perceptions", Journal of Services Marketing, Vol. 22 No. 4, pp. 267-79.

Goi, C.L. and Nee, P.H. (2008), "Alarming credit card debts and bankruptcies among the young", Malaysian Finance Association 2008 Conference Proceedings: Strengthening Malaysia's Position as a Vibrant, Innovative and Competitive Financial Hub, Kuching, Sarawak.

Grønhøj, A. (2007), "The consumer competence of young adults: a study of newly formed households", Qualitative Market Research: An International Journal, Vol. 10 No. 3, pp. 243-64.

Hair, J.F., Black, W.C., Babin, B.J. and Anderson, R.E. (2010), Multivariate Data Analysis: A Global Perspective, 7th ed., Pearson, Upper Saddle River, NJ.

Hayhoe, C.R., Leach, L.J., Turner, P.R., Bruin, M.J. and Lawrence, F.C. (2000), "Differences in spending habits and credit use of college students", The Journal of Consumer Affairs, Vol. 34 No. 1, pp. 113-33.

Heaney, J. (2007), "Generation X and Y's internet banking usage in Australia", Journal of Financial Services Marketing, Vol. 11 No. 3, pp. 196-210.

Heaney, J., Goldsmith, R.E. and Wan Jusoh, W.J. (2005), "Status consumption among Malaysian consumers: exploring its relationship with materialism and attention to social comparison information", Journal of International Consumer Marketing, Vol. 17 No. 4, pp. 83-98.

Hoffman, M.J., McKenzie, K.S. and Paris, S. (2008), "In focus: paper or plastic?", The CPA Journal, Vol. 78 No. 9, pp. 16-20. 
Kara, A., Kaynak, E. and Kucukemiroglu, O. (1994), "Credit card development strategies for the youth market: the use of conjoint analysis", International Journal of Bank Marketing, Vol. 12 No. 6, pp. 30-6.

Kwak, H., Zinkhan, G.M. and Roushanzamir, E.P.L. (2004), "Compulsive comorbidity and its psychological antecedents: a cross-cultural comparison between the US and Korea", Journal of Consumer Marketing, Vol. 21 No. 6, pp. 418-34.

Lachance, M.J. and Legault, F. (2007), "College student's consumer competence: identifying the socialization sources", Journal of Research for Consumers, Vol. 13, pp. 1-5.

Lachance, M.J., Beaudoin, P. and Robitaille, J. (2006), "Quebec young adults' use and knowledge of credit”, International Journal of Consumer Studies, Vol. 30 No. 4, pp. 347-59.

Mandell, L. and Klein, L.S. (2007), "Motivation and financial literacy", Financial Services Review, Vol. 16 No. 2, pp. 105-16.

O'Loughlin, D. and Szmigin, I. (2006), '“I'll always be in debt': Irish and UK student behaviour in a credit led environment", Journal of Consumer Marketing, Vol. 23 No. 6, pp. 335-43.

Park, E.J., Kim, E.Y. and Forney, J.C. (2006), "A structural model of fashion-oriented impulse buying behaviour", Journal of Fashion Marketing and Management, Vol. 10 No. 4, pp. 433-46.

Park, H. and Burns, L.D. (2005), "Fashion orientation, credit card use and compulsive buying", Journal of Consumer Marketing, Vol. 22 No. 3, pp. 135-41.

Penman, S. and McNeill, L.S. (2008), "Spending their way to adulthood: consumption outside the nest", Young Consumers, Vol. 9 No. 2, pp. 155-69.

Peterson, R.A. (1994), "A meta-analysis of Cronbach's coefficient alpha", Journal of Consumer Research, Vol. 21 No. 2, pp. 381-91.

Phau, I. and Woo, C. (2008), "Understanding compulsive buying tendencies among young Australians: the roles of money attitude and credit card usage", Marketing, Intelligence \& Planning, Vol. 26 No. 5, pp. 441-58.

Pirog, S.F. II and Roberts, J.A. (2007), "Personality and credit card misuse among college students: the mediating role of impulsiveness", Journal of Marketing Theory and Practice, Vol. 15 No. 1, pp. 65-77.

Robb, C.A. and Sharpe, D.L. (2009), "Effect of personal financial knowledge on college students' credit card behaviour", Journal of Financial Counselling and Planning, Vol. 20 No. 1, pp. 25-43.

Rutherford, L.G. and DeVaney, S.A. (2009), "Utilizing the theory of unplanned behaviour to understand convenience use of credit cards", Journal of Financial Counselling and Planning, Vol. 20 No. 2, pp. 48-92.

Saravena, A. and Sääksjärvi, M. (2008), "Young compulsive buyers and the emotional roller-coaster in shopping", Young Consumers, Vol. 9 No. 2, pp. 75-89.

Schiffman, L.G. and Kanuk, L.L. (2007), Consumer Behaviour, 9th ed., Pearson Education International, Upper Saddle River, NJ.

Shoham, A. and Brenčič, M.M. (2003), "Compulsive buying behaviour", Journal of Consumer Marketing, Vol. 20 No. 2, pp. 127-38.

Silvera, D.H., Lavack, A.M. and Kropp, F. (2008), "Impulse buying: the role of affect, social influence and subjective wellbeing", Journal of Consumer Marketing, Vol. 25 No. 1, pp. 23-33.

Stone, D.N., Wier, B. and Bryant, S.M. (2008), "Reducing materialism through financial literacy", The CPA Journal, Vol. 78 No. 2, pp. 12-14.

Twenge, J.M. and Campbell, S.M. (2008), "Generational differences in psychological traits and their impact on the workplace", Journal of Managerial Psychology, Vol. 23 No. 8, pp. 862-77.

Warwick, J. and Mansfield, P. (2000), "Credit card consumers: college students' knowledge and attitude", The Journal of Consumer Marketing, Vol. 17 No. 7, pp. 617-26.

Woodruffe, H.R. (1997), "Compensatory consumption: why women go shopping when they're feed up and other stories", Marketing Intelligence \& Planning, Vol. 15 No. 7, pp. 325-34.

$\mathrm{Xu}, \mathrm{Y}$. (2007), "The influence of public consciousness and materialism on young consumers' compulsive spending", Young Consumers, Vol. 9 No. 1, pp. 37-48.

PAGE 252 | YOUNG CONSUMERS | VOL. 12 NO. 32011 
Figure A1 A survey on credit card spending

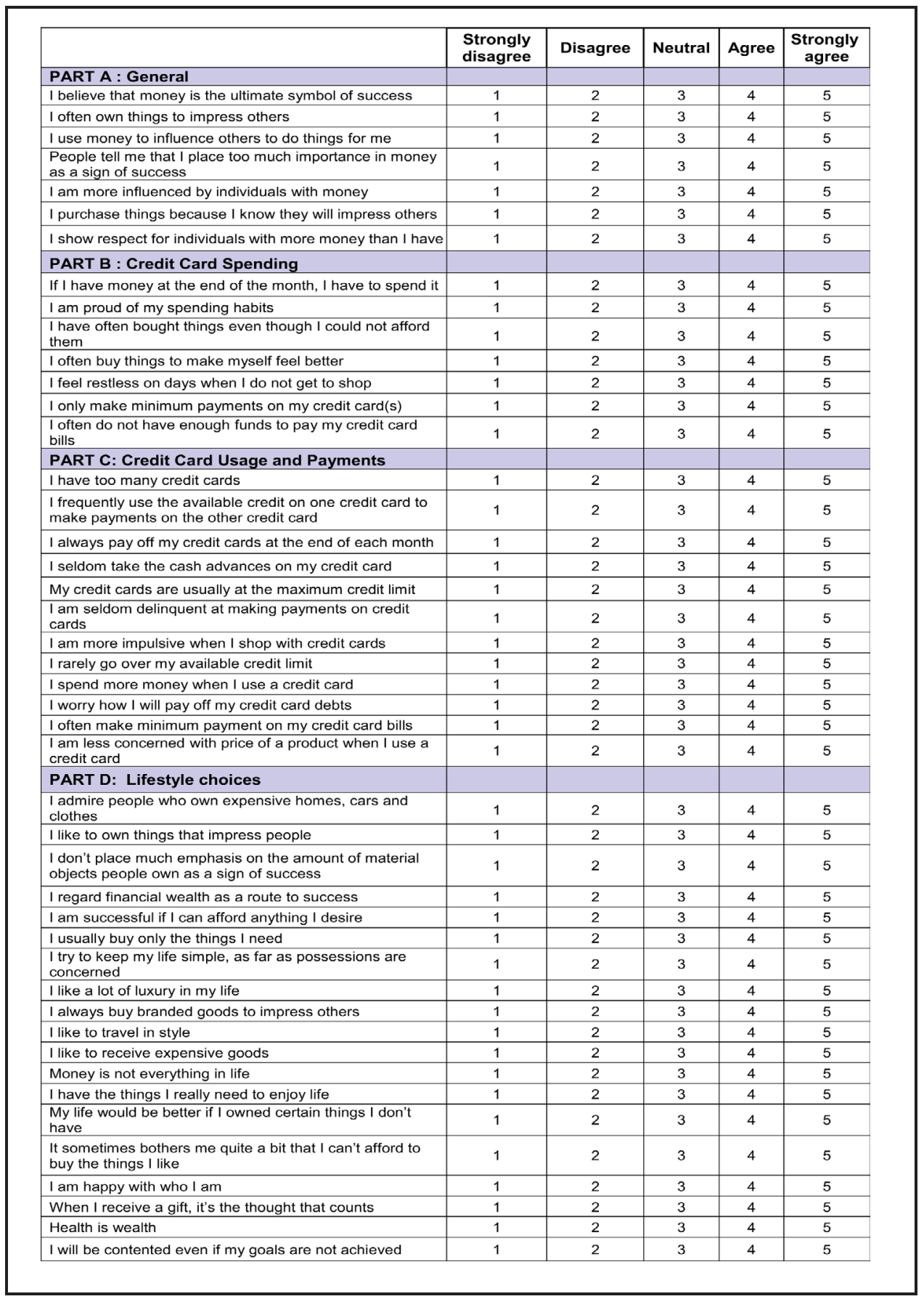

\section{Corresponding author}

Joyce K.H. Nga can be contacted at: joycen@sunway.edu.my

To purchase reprints of this article please e-mail: reprints@emeraldinsight.com Or visit our web site for further details: www.emeraldinsight.com/reprints 